$\mathrm{DOI}$

\title{
ОСОБЛИВОСТІ РЕМОДЕЛЮВАННЯ АРТЕРІЙ ДВАНАДЦЯТИПАЛОЇ КИШКИ ПРИ ОБТУРАЦІЙНОМУ ХОЛЕСТАЗІ
}

\author{
๑С. О. Грабчак, Л. В. Татарчук, М. С. Гнатюк \\ ДвНЗ «Тернопільський державний медичний університет імені І. Я. Горбачевського МОз України»
}

РЕЗЮМЕ. Морфометричними методами вивчено особливості ремоделювання артерій дванадцятипалої кишки при обтураційному холестазі. Встановлено, що в умовах змодельованої патології виражено потовщується стінка, звужується просвіт переважно дрібних артерій, пошкоджуються ендотеліоцити, що ускладнюється їх дисфункцією, погіршанням кровопостачання органа, гіпоксією, дистрофічними, некробіотичними змінами клітин і тканин, осередками інфільтрації та склерозу. Ступінь ремоделювання досліджуваних судин залежав від тривалості обтураційного холестазу.

КЛЮчОВІ СЛОВА: дванадцятипала кишка, артерії, ремоделювання, обтураційний холестаз.

Вступ. Сьогодні під ремоделюванням артерій розуміють зміну їхньої структури та функції в різних патологічних умовах, а даний процес розглядають як відповідь усіх складових стінки судин органів (ендотеліоцитів, гладеньких міоцитів, сполучнотканинних елементів тощо) на різні негативні фактори (гіпоксія, гіперхолестеринемія, гіперглікемія тощо), а також гемодинамічні та нейрогуморальні зміни в організмі [1-3]. Добре вивчені закономірності ремоделювання артерій серцевого м'яза при атеросклерозі, артеріальній та легеневій гіпертензії, серцевій недостатності $[4,5]$. Необхідно зазначити, що особливості ремоделювання артерій дванадцятипалої кишки при обтураційному холестазі досліджені недостатньо [1]. Дванадцятипала кишка завжди втягується в патологічний процес при обтураційному холестазі, і в патогенезі різних ускладнень при даній патології ураження даного органа відіграють немалу роль.

Метою дослідження було вивчення особливостей ремоделювання артерій дванадцятипалої кишки в різні строки обтураційного холестазу.

Матеріал і методи досліджень. В експерименті використано 15 статевозрілих свинейсамців в'єтнамської породи, які були поділені на 4 групи. 1 група склала 6 практично здорових свиней, яким здійснювали лапаротомії, 2 - 3 тварини, у яких забирали матеріал для дослідження через 3 доби механічної жовтяниці, 3 - 3 свині з 7-добовою механічною жовтяницею, 4 - 3 тварини з 28-денним обтураційним холестазом. Механічну жовтяницю моделювали за запропонованим нами способом [6]. Усі оперативні втручання проводили в умовах тіопентал-натрієвого наркозу та з дотриманням правил асептики та антисептики. Евтаназія дослідних тварин здійснювалася кровопусканням в умовах вказаного вище наркозу. Вирізали невеличкі шматочки з різних відділів дванадцятипалої кишки, які фіксували у 10 \% роз- чині нейтрального формаліну. Після фіксації вказані шматочки проводили через етилові спирти зростаючої концентрації і заливали парафіном. Мікротомні зрізи фарбували гематоксиліномеозином, за ван-Гізон, Маллорі, Вейгертом [7].

Морфометрично вивчали артерії дванадцятипалої кишки середнього (51-125 мкм) та дрібного (25-50 мкм) калібрів [8]. При цьому визначали індекс Вогенворта (IB) - відношення площі стінки артерій до площі їхнього просвіту, товщину медії, висоту ендотеліоцитів, діаметр їхніх ядер, ядерно-цитоплазматичні відношення, відносний о6'єм уражених ендотеліоцитів [3, 9]. У кожному мікропрепараті виконували 50 вимірів досліджуваних структур. Необхідно зазначити, що проведені експериментальні дослідження та евтаназію дослідних тварин проводили з дотриманням «Загальних етичних принципів експериментів на тваринах», ухвалених Першим національним конгресом з біоетики (Київ, 2001) та відповідно до Європейської конвенції про захист хребетних тварин, що використовуються в дослідних та інших наукових цілях. Отримані кількісні дані обробляли статистично. Обробка даних виконана у відділі системних статистичних досліджень Тернопільського державного медичного університету імені І. Я. Горбачевського у програмному пакеті Statsoft STATISTIKA. Різницю між порівнюваними величинами визначали за критеріями Стьюдента і Манна-Уітні [10].

Результати й обговорення. Дані, отримані в результаті проведеного дослідження, представлені в таблиці 1. Аналізом показаних у названій таблиці морфометричних параметрів встановлено, що вже на третю добу після змодельованої патології деякі з них суттєво змінилися. При цьому більш вираженою структурна перебудова їх стінки була в артеріях дрібного калібру дванадцятипалої кишки. Так, IB у цей період експерименту в артеріях середнього калібру зріс на 13,4 \%, у 
Огляди літератури, оригінальні дослідження, погляд на проблему

дрі6них - на 18,0 \%, а товщина медії - відповідно на 8,5 і 12,0\%. Збільшення наведених вище морфометричних параметрів свідчило про зниження пропускної здатності досліджуваних артерій $[3,8]$. У даних умовах експерименту спостерігалася тенденція до зростання просторових характеристик ендотеліоцитів, що можна пояснити набряком клітин $[9,11]$. Нерівномірне збільшення параметрів цитоплазми ендотеліоцитів та їхніх ядер призводило до порушення ядерно-цитоплазматичних відношень у цих клітинах. Так, у артеріях середнього калібру цей показник зріс на $11,1 \%$, а у дрібних судинах - на $12 \%$. У досліджуваних артеріях збільшувалася кількість пошкоджених ендотеліоцитів. Відносний об'єм названих структур у судинах середнього калібру склав $(9,5 \pm 0,42) \%$, а у дрі6них артеріях - $(12,80 \pm 0,45) \%$.

На 7-у добу експерименту IB середніх артерій дванадцятипалої кишки зріс у 1,37 раза, а дрібних артерій - у 1,4 раза. У даних експериментальних умовах товщина медії досліджуваних судин збільшилася відповідно на 11,2 та 18,7 \%. Ядерноцитоплазматичні відношення в ендотеліоцитах артерій середнього калібру зросли на 14,8, а у вказаних клітинах дрібних артерій - на 16 \%. Деякі дослідники вказують, що виражені зміни співвідношень між просторовими характеристиками ядра та цитоплазми клітини свідчать про порушення клітинного структурного гомеостазу [9], що може призводити до дисфункції органа.

Найвираженіші зміни у судинах були виявлені через 28 діб після моделювання обтураційного холестазу. При цьому IB у артеріях середнього калібру зріс у 1,52 , у дрібних -у 1,57 раза, а товщина медії відповідно на 17,5 та $30,0 \%$. Висота ендотеліоцитів при цьому в артеріях середнього калібру збільшилася з $(6,40 \pm 0,12)$ до $(6,85 \pm 0,15)$ мкм, $\mathrm{P}<0,05)$, тобто на $7 \%$, а діаметр їхніх ядер - на $16,4 \%$.

Ядерно-цитоплазматичні відношення у досліджуваних структурах виявилися також збільшеними на $16,7 \%$. Останній морфометричний параметр у артеріях дрібного калібру зріс на $20,0 \%$. Описані зміни досліджуваних співвідношень свідчили про порушення структурного гомеостазу в ендотеліоцитах, яке було більш вираженим у дрібних судинах.

Відносний об'єм уражених ендотеліоцитів у цей період експерименту в артеріях середнього калібру дорівнював $(26,10 \pm 1,20) \%$, а у дрібних судинах - $(36,40 \pm 1,50) \%$. Наведені цифрові величини статистично достовірно відрізнялися між собою і останній морфометричний параметр перевищував попередній на $10,3 \%$.

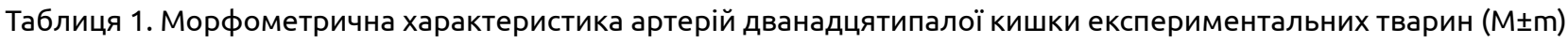

\begin{tabular}{|c|c|c|c|c|}
\hline \multirow{2}{*}{ Показник } & \multicolumn{4}{|c|}{ Групи спостереження } \\
\hline & 1 & 2 & 3 & 4 \\
\hline \multicolumn{5}{|c|}{ Середні артерії } \\
\hline IB & $255,6 \pm 3,6$ & $289,8 \pm 4,2 * *$ & $350,2 \pm 4,8 * * *$ & $388,5 \pm 5,4 * * *$ \\
\hline TM, MKM & $18,80 \pm 1,14$ & $20,40 \pm 1,20$ & $20,90 \pm 1,08$ & $22,10 \pm 0,96^{*}$ \\
\hline $\begin{array}{l}\text { Висота ендотеліоцитів, } \\
\text { Мкм }\end{array}$ & $6,40 \pm 0,12$ & $6,60 \pm 0,09$ & $6,70 \pm 0,12$ & $6,85 \pm 0,15^{*}$ \\
\hline $\begin{array}{l}\text { Діаметр ядер } \\
\text { ендотеліоцитів, мкм }\end{array}$ & $3,30 \pm 0,07$ & $3,60 \pm 0,06$ & $3,80 \pm 0,12$ & $3,84 \pm 0,12$ \\
\hline $\begin{array}{l}\text { Ядерно-цитоплазматичні } \\
\text { відношення }\end{array}$ & $0,270 \pm 0,009$ & $0,300 \pm 0,006^{*}$ & $0,310 \pm 0,009 * *$ & $0,315 \pm 0,008^{* *}$ \\
\hline $\begin{array}{l}\text { Відносний об'єм уражених } \\
\text { ендотеліоцитів, \% }\end{array}$ & $2,45 \pm 0,06$ & $9,50 \pm 0,42 * * *$ & $14,30 \pm 0,48 * * *$ & $26,10 \pm 1,20 * * *$ \\
\hline \multicolumn{5}{|c|}{ Дрібні артерії } \\
\hline IB & $900,3 \pm 12,7$ & $1062,4 \pm 15,1^{* *}$ & $1264,6 \pm 16,2 * * *$ & $1413,7 \pm 18,3^{* * *}$ \\
\hline TM, MKM & $13,30 \pm 0,72$ & $14,90 \pm 0,66$ & $15,80 \pm 0,63^{*}$ & $17,30 \pm 0,57^{*}$ \\
\hline $\begin{array}{l}\text { Висота ендотеліоцитів, } \\
\text { Мкм }\end{array}$ & $6,15 \pm 0,12$ & $6,46 \pm 0,15$ & $6,60 \pm 0,12^{* *}$ & $6,87 \pm 0,15^{*}$ \\
\hline $\begin{array}{l}\text { Діаметр ядер } \\
\text { ендотеліоцитів, мкм }\end{array}$ & $3,11 \pm 0,06$ & $3,40 \pm 0,08^{*}$ & $3,55 \pm 0,07 * *$ & $3,76 \pm 0,05^{* *}$ \\
\hline $\begin{array}{l}\text { Ядерно-цитоплазматичні } \\
\text { відношення }\end{array}$ & $0,250 \pm 0,006$ & $0,280 \pm 0,007 * *$ & $0,290 \pm 0,009 * *$ & $0,300 \pm 0,007^{* * *}$ \\
\hline $\begin{array}{l}\text { Відносний об'єм уражених } \\
\text { ендотеліоцитів, \% }\end{array}$ & $2,30 \pm 0,09$ & $12,80 \pm 0,45^{* * *}$ & $18,20 \pm 0,51 * * *$ & $36,40 \pm 1,50 * * *$ \\
\hline
\end{tabular}

Примітка. Зірочкою позначені величини, що статистично достовірно відрізняються від контрольних (* $-\mathrm{P}<0,05 ;{ }^{* *}-\mathrm{P}<0,01$; $* * *-P<0,001)$. 
Огляди літератури, оригінальні дослідження, погляд на проблему

Отримані морфометричні показники досліджуваних судин свідчать, що обтураційний холестаз призводить до вираженого ремоделювання артерій дванадцятипалої кишки дрібного та середнього калібру. При цьому необхідно також зазначити, що більш виражені зміни знайдені в артеріях дрібного калібру, яким належить основна роль у кровопостачанні органів $[8,9]$.

Гістологічно у стінці дванадцятипалої кишки виявлялися виражені судинні розлади, набряк строми, вогнища дистрофічно і некробіотично змінених епітеліоцитів і ендотеліоцитів, їх десквамацію, клітинні інфільтрати в стромі, проліферацію ендотеліоцитів. Останнє свідчило про наявність гіпоксії $[3,8]$. Спостерігали також набряк ендотеліоцитів, просякання їхньої мембрани білками плазми, дистрофію і некроз цих клітин. У деяких судинах спостерігались вогнища фібриноїдного набухання та некрозу, що свідчило про їхнє виражене пошкодження. Проведене дослідження свідчить, що при тривалій механічній жовтяниці пошкоджуються ендотеліоцити артерій дванадцятипалої кишки. При 28-добовому обтураційному холестазі у оболонках досліджуваного органа виявлялися склеротичні процеси.

Згідно з сучасними науковими поглядами, ендотелій - це активний ендокринний орган, який синтезує різні біологічно активні субстанції, необхідні для регуляції життєво важливих процесів організму (згортання крові, регуляція тонусу судин, функціональна активність нирок, скоротливість серця, дифузія води, іонів, продуктів метаболізму $[3,4]$. Ендотеліоцити також здійснюють бар'єрну, продукційну, гемостатичну, метаболічну, транспортну та репаративну функції. Ці клітини відіграють також важливу роль у ремоделюванні судинної стінки в різних фізіоло- гічних та патологічних умовах $[4,5]$. Серед чинників, синтезованих ендотелієм, важлива роль належить оксиду азоту (NO). Пошкодження ендотеліоцитів призводить до їхньої дисфункції, блокади NO-синтази, зменшення синтезу NO i активації процесів його деградації. Ці явища супроводжуються спазмами та звуженням судин, що не тільки підтримує, але й посилює гіпоксію, набряк, дистрофію та некробіотичні зміни в тканинах $[4,12]$. На основі отриманих результатів проведеного дослідження та за даними літератури можна стверджувати, що тривалий обтураційний холестаз призводить до вираженої структурної перебудови артерій дванадцятипалої кишки, потовщення їх стінки, звуження просвіту, пошкодження ендотеліоцитів і супроводжується погіршенням кровопостачання органа.

Висновок. Обтураційний холестаз призводить до вираженої структурної перебудови артерій дванадцятипалої кишки, характеризується потовщеням їхньої стінки, звуженням їх просвіту, ураженням ендотеліоцитів, супроводжується погіршенням кровопостачання досліджуваних структур, гіпоксією, дистрофією та некрозом тканин. Вираженість структурної перебудови артерій дванадцятипалої кишки залежить від тривалості обтураційного холестазу. Морфологічні зміни у судинах дванадцятипалої кишки при обтураційному холестазі варто враховувати в практичній медицині при профілактиці, діагностиці та лікуванні вказаної патології.

Перспективи подальших досліджень. Всебічне адекватне вивчення структурної перебудови артерій дванадцятипалої кишки в умовах обтураційного холестазу дозволить суттєво покращити діагностику, корекцію та профілактику досліджуваної патології.

\section{ЛІТЕРАТУРА}

1. Шульгай А. Г. Морфологічна характеристика змін тонкої і товстої кишки при експериментальній механічній жовтяниці / А. Г. Шульгай // Вісник наукових досліджень - 2004. - № 1. - С. 89-91.

2. Жорняк П. В. Морфологічні зміни в дванадцятипалій кишці після виконання різних методів резекції шлунка / П. В. Жорняк, Г. Я. Костюк, П. К. Загниборода // Вісник проблем біології і медицини. - 2007. - № 1. - С. 120-123.

3. Гнатюк М. С. Морфометрична оцінка вікових особливостей ремоделювання артерій дванадцятипалої кишки / М. С. Гнатюк, Л. В. Татарчук, М.В.Данів // Клінічна анатомія та оперативна хірургія. - 2009. - Т. 8, № 4 (30). - C. 54-57.

4. Калінкіна Н. В. Ремоделювання артерій при серцево-судинних захворюваннях / Н. В. Калінкіна,

О. К. Кашанська, Є. В. Кетінг // Серце і судини. - 2004. № 4 (8). - С. 87-91.

5.ЧуйкоН.Я.Морфометричнийаналіз патологічних змін в артеріях при метаболічному синдромі, ускладненому інсультом / Н. Я. Чуйко // Клінічна та експериментальна патологія. - 2014. - Т. 13, № 2 (48). - С. 155-157.

6. Патент UA78273, MПК G 09B23/28(2006/01) Спосі6 моделювання механічної жовтяниці / М. С. Гнатюк № U201211327; заявл.01.10.2012; опубл.11.03.2013, Бюл. № 5.

7. Сорочинников А. Г. Гистологическая и микроскопическая техника / А. Г. Сорочинников, А. Е. Дорошевич. - М. : Медицина, 1997. - 448 с.

8. Шорманов С. В. Адаптационные структуры артериального русла плода и плаценты в условиях хронической фетоплацентарной недостаточности / 
Огляди літератури, оригінальні дослідження, погляд на проблему

С. В. Шорманов, А. В. Павлов, А. Н. Гансбургский // Архив патологии. - 2014. - № 3. - С. 41-46.

9. Автандилов Г. Г. Основы количественной патологической анатомии / Г. Г. Автандилов. - М. : Медицина, 2002. -240 C.

10. Лапач С. Н. Статистические методы в медикобиологических исследованиях Excell / С. Н. Лапач, А. В. Губенко, П. Н. Бабич. - К. : Морион, 2001. - 410 с.
11. Возможности современных методов диагностики и обоснование лечебной тактики при механической желтухе / Ю. М. Стойко, А. Л. Левчук, В. Г. Бардаков, П. С. Ветшев // Вестн. хирургической гастроэнтерологии. - 2008. - № 2. - С. 24-32.

12. Laine L. Gastric mucosal defence and cytoprotection bench to bedside / L. Laine, K. Takenchi, A. Tarnawski // Gastroenterology. - 2008. - № 135. - P. 41-60.

\section{PECULIARITIES REMODELING ARTERIES DUODENUM AT OBTURTIVE CHOLESTASIS \\ @S. O. Grabchac, L. V. Tatarchuk, M. S. Hnatjuk \\ I. Horbachevsky Ternopil State Medical University}

SUMMARY. The peculiarities of remodeling duodenum have been studies morphometric methods of obturative cholestasis. It was established that the model pathology results in thickening of the arterial wall, narrowing of their spaces, affection of small arteries, endotheliocytes that led to their dysfunction, decreasing of organ blood supply, hypoxia, dystrophic and necrobiolic changes of tissues and cells. The degree remodeling investigative of vessels dipended from continuance of obturative cholestasis.

KEY WORDS: duodenum, arteries, remodeling, obturative cholestasis.

Отримано 9.02.2016 